\title{
ПОКАЗНИКИ ФЕРТИЛЬНОСТІ ЩУРІВ ТА РІВЕНЬ ЛЕПТИНУ В ПЛАЗМІ КРОВІ ЗА УМОВ ВПЛИВУ ВИСОКОКАЛОРІЙНИХ ДІЄТ
}

Вступ. Вплив ожиріння на плідність чоловіків є предметом багатьох досліджень, а молекулярні механізми, що лежать в основі цього взаємозв'язку, активно вивчає наукова спільнота. Лептин є пептидним гормоном, який в основному синтезується у жировій тканині та підтримує енергетичний гомеостаз організму. Крім того, він активно залучений у регуляцію репродуктивної фрункції через модуляцію гіпоталамо-гіпофрізарно-гонадної осі. Ймовірно, лептин можна розглядати як біомаркер, що поєднує метаболічний статус із репродуктивною системою організму.

Мета дослідження - оцінити вплив висококалорійних дієт на показники фрертильності щурів-самців і рівень лептину в плазмі крові.

Методи дослідження. Дослідження було проведено на 30 білих нелінійних щурах-самцях масою 250-300 г, яких поділили на 3 групи по 10 тварин у кожній: щури контрольної групи (КГ) споживали стандартний корм; тварини дослідних груп отримували високожирову дієту (ВЖД) і дієту з високим вмістом жиру та цукру (ВЖЦД) відповідно. Утримували лабораторних тварин на зазначених раціонах протягом 7 тижнів. Після евтаназії щурів проводили їх морфометричні заміри, на основі яких обчислювали індекс Лі, тестикулярний коефріцієнт та коефріцієнт вісцерального жиру. Кров для дослідження забирали з хвостових судин тварин у еппендорфи з гепарином. Отриманий матеріал 5 хв центрифругували при $800 \mathrm{~g}$, після чого відбирали плазму для подальших досліджень. Суспензію сперматозоїдів готували з каудальної частини епідидимісів яєчок. Розраховували загальну кількість статевих клітин та їх рухливість. Життєздатність сперматозоїдів досліджували иляхом їх фрарбування фрлуоресцентним барвником пропідій йодидом. Концентрацію лептину в плазмі крові визначали методом імунофрерментного аналізу.

Результати й обговорення. Утримування щурів на ВЖД і ВЖЦД протягом 7 тижнів суттєво не позначилося на прирості маси тіла. Індекс Лі незначно відрізнявся між дослідними групами (p=0,59). Однак коефріцієнт вісцерального жиру в групі ВЖЦД був на 40 \% вищим порівняно з КГ (p=0,04). Не було виявлено істотної різниці між дослідними групами щодо кількості сперматозоїдів $(p=0,72)$, рухливості $(p=0,63)$ та життєздатності ( $p=0,87)$. Дієта з високим вмістом жиру і цукру спричиняла зростання концентрації лептину в плазмі крові щурів на 14 \% від вихідних даних $(p=0,01)$.

Висновок. Короткострокове перебування на раціоні з високим вмістом жиру і цукру викликає метаболічні зміни, на що вказує значне зростання відносної частки жирової тканини та рівня лептину в плазмі крові.

КЛЮЧОВІ СЛОВА: лептин; ожиріння; висококалорійні дієти; фрертильність.

ВСТУП. Зміни нутритивного статусу і, відповідно, пов'язаної з ним маси тіла позначаються на гормональному фоні особин. 3 метою регуляції енергетичного гомеостазу в жировій тканині синтезується ряд адипокінів, серед яких - пептидний гормон лептин. Оскільки циркулюючий рівень лептину в сироватці крові прямо пропорційний індексу маси тіла та жировій масі, його вважають біомаркером ожиріння [1]. ще донедавна існувала думка про те, що основна роль лептину - регуляція споживання їжі особиною та підтримка енергетичного балансу організму [2]. Проте дослідження останніх десятиліть підтверджують, що лептин бере участь також і в (c) Н. М. Козопас, Г. В. Максимюк, 2021. інших метаболічних процесах, зокрема обміні глюкози; завдяки модуляції гіпоталамо-гіпофрізарно-гонадної осі, він $€$ важливим чинником нормального статевого дозрівання та функціонування репродуктивної системи [2]. Крім того, секрецію лептину частково регулюють інші гормони, зокрема статеві стероїди. Естрогени стимулюють вивільнення лептину адипоцитами, тоді як андрогени (тестостерон) чинять інгібуючий вплив на нього [3-5].

Вплив ожиріння на параметри плідності чоловіків є предметом багатьох досліджень, однак молекулярні механізми, що лежать в основі цього взаємозв'язку, досі не до кінця з'ясовано. Імовірно, лептин може слугувати біомаркером, 
який поєднує метаболічний статус із репродуктивною віссю організму.

Мета дослідження - оцінити вплив висококалорійних дієт на показники фертильності щурів-самців і рівень лептину в плазмі крові.

МЕТОДИ ДОСЛІДЖЕННЯ. Дослідження було проведено на 30 білих нелінійних щурах-самцях масою 250-300 г, яких утримували у стандартних умовах віварію. Під час роботи керувалися загальними етичними принципами Європейської конвенції про захист хребетних тварин, що використовуються для дослідних та інших наукових цілей (Страсбург, 1986) та Законом України “Про захист тварин від жорстокого поводження" (№ 1759-VI від 15 грудня 2009 р.).

Усіх щурів випадковим чином поділили на 3 групи по 10 тварин у кожній: щури контрольної групи (КГ) споживали стандартний корм; тварини дослідних груп отримували високожирову дієту (ВЖД) і дієту з високим вмістом жиру та цукру (ВЖЦД) відповідно.

Кров для дослідження забирали з хвостових судин щурів у еппендорфи, що містили гепарин. Отриманий матеріал 5 хв центрисуугували при 800 g, після чого відбирали плазму та заморожували при $-20{ }^{\circ} \mathrm{C}$ для подальших досліджень.

Утримували лабораторних тварин на різних раціонах протягом 7 тижнів. Контрольне зважування здійснювали 2 рази на тиждень. Перед декапітацією самців зважували та вимірювали їх аноректальну довжину. Після евтаназії у тварин висікали і реєстрували масу яєчок та вісцерального жиру. На основі отриманих даних обчислювали індекс Лі, тестикулярний коефріцієнт і коефріцієнт вісцерального жиру. Індекс Лі - показник, що корелює з жировою масою, його розраховують як співвідношення кубічного кореня маси тіла в грамах до назоанальної довжини в міліметрах, помножене на 1000 [6].

3 метою приготування суспензії сперматозоїдів ретельно відділяли хвости епідидимісів яєчок (каудальну частину) та переносили їх у чашку Петрі, що містила 3-4 мл попередньо підігрітого до $37{ }^{\circ} \mathrm{C}$ модисрікованого розчину Тироде $(131,89 \mathrm{mM} \mathrm{NaCl}, 2,68 \mathrm{mM} \mathrm{KCl}, 0,49 \mathrm{mM}$ $\mathrm{MgCl}_{2} \cdot 6 \mathrm{H}_{2} \mathrm{O}, 0,36 \mathrm{mM} \mathrm{NaH_{2 }} \mathrm{PO}_{4} \cdot 2 \mathrm{H}_{2} \mathrm{O}, 2,68 \mathrm{mM}$ $\mathrm{CaCl}_{2}, 5,56$ мМ глюкози, 20,0 мМ HEPES, 4 мг/мЛ бичачого сироваткового альбуміну). На кожному хвості епідидимісу робили 4-5 поперечних та 2 повздовжніх розрізи, після чого очікували 5-10 хв, щоб статеві клітини дифрундували в розчин. Готову суспензію переносили у пробірку.

Концентрацію сперматозоїдів визначали в камері Горяєва, а загальну кількість статевих клітин розраховували, помноживши отриману концентрацію на об'єм готової суспензії. Рухли- вість оцінювали за допомогою світлового мікроскопа, підраховуючи відсоток рухливих та нерухливих клітин [7]. Для визначення життєздатності використовували методику фрарбування клітин пропідій йодидом (“Sigma”, США). Флуоресценцію забарвлених клітин оцінювали за допомогою мікроскопа "Olympus IX73". Аналізували щонайменше 200 сперматозоїдів для кожного зразка. Концентрацію лептину в плазмі крові визначали методом імуноферментного аналізу за допомогою планшетного напівавтоматичного фоотометра "Stat-fax-303" ("Awareness Technology Inc.", США) із застосуванням комерційних наборів "DBC" ("Diagnostics Biochem Canada Inc.", Канада).

Для статистичної обробки результатів використовували дисперсійний аналіз (ANOVA) і Tukey test для кількох попарних порівнянь. Достовірність відмінностей між незалежними даними при неправильному розподілі оцінювали за допомогою U-критерію Манна - Уїтні. Показник $p<0,05$ вважали статистично значущим.

РЕЗУЛЬТАТИ Й ОБГОВОРЕННЯ. ВСТаНОВлено, що після завершення семитижневого споживання висококалорійної дієти маса тіла тварин груп ВЖД та ВЖЦД суттєво не відрізнялася від маси тіла щурів КГ, які перебували на стандартному раціоні. Проте у тварин групи ВЖЦД приріст маси тіла становив лише $19 \%$, тоді як у щурів КГ та групи ВЖД маса тіла збільшувалась у середньому на 26 \% порівняно 3 вихідною масою. Індекс Лі несуттєво відрізнявся між дослідними групами ( $p=0,59)$. Однак варто зауважити, що коесріцієнт вісцерального жиру в тварин групи ВЖЦД був на 40 \% вищим порівняно з КГ ( $p=0,04)$, незважаючи на найменший приріст маси тіла (табл.). Результати аналізу даних, які ми отримали, вказують на відсутність істотної різниці між дослідними групами щодо основних показників спермограми: кількості сперматозоїдів $(p=0,72)$, рухливості $(p=0,63)$ та життєздатності ( $p=0,87)$.

Встановлено зростання концентрації лептину (рис.) в плазмі крові щурів після семитижневого дієтичного харчування порівняно з вихідними показниками $(p<0,01)$. У тварин, які перебували на раціоні з високим вмістом жиру і цукру (рис.), спостерігали найбільш істотне зростання рівня лептину - 14 \% від початкових даних ( $p=0,01)$. Отримані дані узгоджуються з попередніми дослідженнями, які вказують на зв'язок ожиріння з підвищенням сироваткових рівнів лептину $[8,9]$.

Зауважимо, що, за результатами кореляційного аналізу, встановлено помірний прямий взаємозв'язок між концентрацією лептину в 
Таблиця - Вплив різнокомпонентних дієт на морфометричні показники тіла самців та параметри сперми

\begin{tabular}{||l|c|c|c||}
\hline \multicolumn{1}{||}{ Показник } & КГ & ВЖД & ВЖЦД \\
\hline \multicolumn{3}{|c|}{ Морфометричні показники } & $15,0 \pm 5,0$ \\
\hline Приріст маси тіла, \% & $25,0 \pm 9,0$ & $26,0 \pm 10,0$ & $333,2 \pm 7,9$ \\
\hline Індекс Лі, г/см & $325,2 \pm 7,9$ & $329,6 \pm 5,2$ & $2,9 \pm 0,5^{\star}$ \\
\hline Коесріцієнт вісцерального жиру, \% & $2,1 \pm 0,3$ & $2,4 \pm 0,8$ & $1,2 \pm 0,3$ \\
\hline Тестикулярний коесріцієнт, \% & $1,2 \pm 0,1$ & $1,2 \pm 0,2$ & 185,0 \\
\hline \multicolumn{3}{|c|}{ Спермограма } \\
\hline Загальна кількість сперматозоїдів, & 200,0 & 243,0 & $(155,0 ; 249,0)^{\text {a }}$ \\
млн & $(153,0 ; 296,0)^{\mathrm{a}}$ & $(168,0 ; 297,0)^{\mathrm{a}}$ & $60,0 \pm 11,0$ \\
\hline Рухливість, \% & $78,0 \pm 9,0$ & $65,0 \pm 11,0$ & $39,0 \pm 19,0$ \\
\hline Життєздатність, \% & $47,0 \pm 17,0$ & $44,0 \pm 16,0$ & \\
\hline
\end{tabular}

Примітки:

1. Дані наведено як середнє арифметичне значення (М) \pm середньоквадратичне відхилення (б), окрім випадків, які позначено ${ }^{\text {a }}$

2. а - дані подано як медіану та міжквартильний інтервал, зважаючи на несиметричність розподілу даних.

3. * - статистично значущі відмінності порівняно з показниками щурів КГ $(p<0,05)$.

плазмі крові та індексом Лі (r=0,36, p=0,05), однак не спостерігали статистично значущого зв'язку 3 коефіцієнтом вісцерального жиру ( $r=-0,08$, $\mathrm{p}=0,72)$. Ці результати можна зіставити з даними клінічного дослідження A. Liuzzi та ін. [10], які показали, що тяжке абдомінальне ожиріння $€$ негативною детермінантою концентрації лептину, тобто у пацієнтів з більшою кількістю вісцерального жиру виявляли відносно нижчі його значення.

Результати досліджень C. Antinozzi та ін. [9] підтверджують зростання рівня лептину в чоловіків із надмірною масою тіла та ожирінням, однак вони не встановили статистичних відмінностей між параметрами спермограми в групах. Ці результати узгоджуються 3 даними нашої роботи. Однак інші дослідження на тваринних моделях показують, що дієтіндуковане ожиріння негативно впливає на параметри сперми [11, 12]. Припускаємо, що такі розбіжності можуть бути пов'язані з рядом чинників, які необхідно враховувати на етапі планування експерименту. Наприклад, ми утримували лабораторних тварин на спеціальному харчуванні протягом 7 тижнів, проте в більшості досліджень для моделювання ожиріння тривалість дієт становить від 12 тижнів $[11,13,14]$. Імовірно, термін, який ми обрали, був недостатньо тривалим для більш значного набору маси тіла. Проте було встановлено, що навіть короткострокове перебування на дієті 3 високим вмістом жиру і цукру викликає метаболічні зміни, на що вказує значне зростання відносної частки жирової тканини та рівня лептину в плазмі крові.

ВИСНОВКИ. 1. Короткострокове утримування щурів на високожировій дієті й дієті з високим

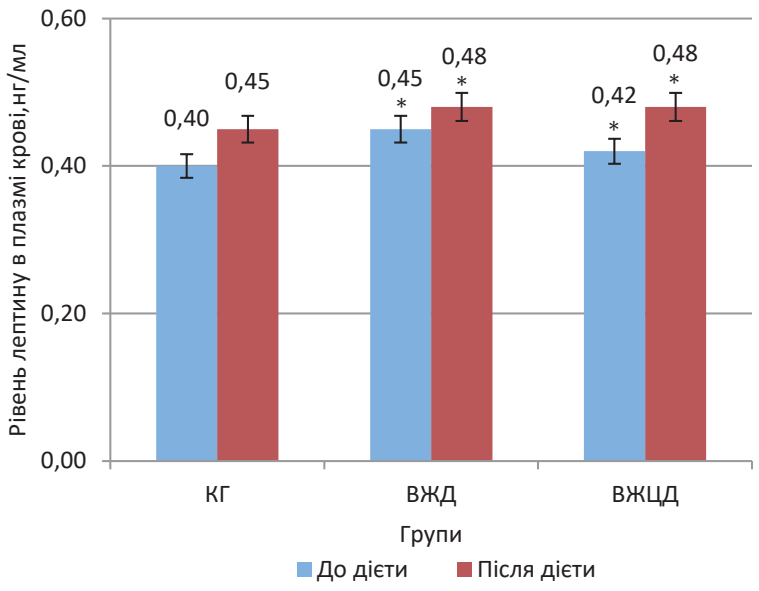

Рис. Концентрація лептину в плазмі крові щурів до та після утримування тварин на висококалорійних дієтах.

Примітка. * - статистично значущі відмінності порівняно з показниками щурів КГ ( $p<0,05)$.

вмістом жиру і цукру несуттєво позначилося на прирості маси тіла щурів, також не було виявлено статистично значущої відмінності між показниками індексу Лі серед дослідних груп.

2. Дієта з високим вмістом жиру і цукру спричиняла у тварин значне збільшення частки вісцерального жиру і зростання концентрації лептину в плазмі крові.

3. Не виявлено статистично достовірної різниці між групами щодо загальної кількості сперматозоїдів, рухливості та життєздатності статевих клітин.

4. 3 огляду на отримані дані, вважаємо, що для моделювання ожиріння та вивчення впливу надмірної маси тіла на фрертильність самців краще використовувати дієту з високим вмістом жиру і цукру. Проте термін перебування тварин нацьому раціоні повинен бути значно тривалішим. 


\section{СПИСОК ЛІТЕРАТУРИ}

1. Body mass index and serum leptin concentration independently estimate percentage body fat in older adults / C. E. Ruhl, T. B. Harris, J. Ding [et al.] // Am. J. Clin. Nutr. - 2007. - 85 (4). - P. 1121-1126.

2. Human leptin: from an adipocyte hormone to an endocrine mediator / M. Wauters, R. V. Considine, L. F. Van Gaal [et al.] // Eur. J. Endocrinol. - 2000. 143 (3). - P. 293-311.

3. The importance of leptin to reproduction / G. V. Childs, A. K. Odle, M. C. MacNicol, A. M. MacNicol// Endocrinology. - 2021. - 162 (2). - P. 1-18.

4. Leptin and reproductive function / G. J. Hausman, C. R. Barb, C. A. Lents [et al.] // Biochimie. - 2012. 94 (10). - P. 2075-2081.

5. Diet-induced obesity in the rat: A model for gestational diabetes mellitus / K. Holemans, S. Caluwaerts, L. Poston, F. A. Van Assche // Am. J. Obstet. Gynecol. 2004. - 190 (3). - P. 858-865.

6. Obesity induction with high fat sucrose in rats / A. B. Malafaia, P. A. N. Nassif [et al.] // Arq. Bras. Cir. Dig. - 2013. - 26 (1). - P. 17-21.

7. WHO laboratory manual for the Examination and processing of human semen / World Health Organization // WHO laboratory manual for the Examination and processing of human semen (http://whqlibdoc.who.int/publications/2010/9789241547789_eng.pdf).

8. Obesity is associated with increased seminal insulin and leptin alongside reduced fertility parameters in a controlled male cohort / K. Leisegang, P. J. Bouic,

\section{REFERENCES}

1. Ruhl, C.E., Harris, T.B., Ding, J., Goodpaster, B.H., Kanaya, A.M. (2007). Body mass index and serum leptin concentration independently estimate percentage body fat in older adults. The American Journal of Clinical Nutrition, 85 (4), 1121-1126.

2. Wauters, M., Considine, R.V., \& Van Gaal, L.F. (2000). Human leptin: from an adipocyte hormone to an endocrine mediator. European Journal of Endocrinology, 143 (3), 293-311.

3. Childs, G.V., Odle, A.K., MacNicol, M.C., \& MacNicol, A.M. (2021). The importance of leptin to reproduction. Endocrinology, 162 (2), 1-18.

4. Hausman, G.J., Barb, C.R., \& Lents, C.A. (2012). Leptin and reproductive function. Biochimie, 94 (10), 2075-2081.

5. Holemans, K., Caluwaerts, S., Poston, L., Van Assche, F.A. (2004). Diet-induced obesity in the rat: A model for gestational diabetes mellitus. American Journal of Obstetrics and Gynecology, 190 (3), 858-865.

6. Malafaia, A.B., Nassif, P.A.N., Ribas, C.A.P., Ariede, B.L., Sue, K.N., \& Cruz, M.A. (2013). Obesity induction with high fat sucrose in rats. Arquivos brasileiros de cirurgia digestiva. Brazilian Archives of Digestive Surgery, 26 (1), 17-21.

7. (2010). World Health Organization. WHO laboratory manual for the Examination and processing of human semen. World Health Organization.
R. Menkveld [et al.] // Endocrinol. - 2014. - 12 (1). P. 1-12.

9. Exploratory analysis in the differences in blood serum and seminal plasma of adipose-tissue related peptides in obese and non-obese men and their correlations with semen parameters / C. Antinozzi, M. Lista, L. Caponecchia [et al.] // Front. Endocrinol. (Lausanne). 2021. - 12. DOI:10.3389/FENDO.2021.681939.

10. Serum leptin concentration in moderate and severe obesity: Relationship with clinical, anthropometric and metabolic factors / A. Liuzzi, G. Savia, M. Tagliaferri [et al.] // Int. J. Obes. - 1999. - 23 (10). - P. 1066-1073.

11. Obesogenic environment by excess of dietary fats in different phases of development reduces spermatic efficiency of wistar rats at adulthood: correlations with metabolic status / V. Reame, E. Z. Pytlowanciv, D. L. Ribeiro [et al.] // Biol. Reprod. - 2014. - 91 (6). DOI:10.1095/ BIOLREPROD.114.121962.

12. Diet-induced obesity in rats leads to a decrease in sperm motility / C. D. B. Fernandez, F. F. Bellentani, G. S. A. Fernandes [et al.] // Reprod. Biol. Endocrinol. 2011. - 9. - P. 32.

13. High-fat diet-induced obesity Rat model: a comparison between Wistar and Sprague-Dawley Rat / C. Marques, M. Meireles, S. Norberto [et al.] // Adipocyte. 2016. - 5 (1). - P. 11-21.

14. Experimental model to induce obesity in rats 1 Modelo experimental para induzir obesidade em ratos / V. Von Diemen, E. N. Trindade, M. Roberto [et al.] // Acta Cirúrgica Bras. - 2006. - 21 (6). - P. 425.

8. Leisegang, K., Bouic, P.J., Menkveld, R., Henkel, R.R. (2014). Obesity is associated with increased seminal insulin and leptin alongside reduced fertility parameters in a controlled male cohort. Reproductive Biology and Endocrinology, 12 (1), 1-12.

9. Antinozzi, C., Lista, M., Caponecchia, L., Salacone, P., Minganti, C., Battaglia, F.A., et al. (2021). Exploratory analysis in the differences in blood serum and seminal plasma of adipose-tissue related peptides in obese and non-obese men and their correlations with semen parameters. Frontiers in Endocrinology, 12.

10. Liuzzi, A., Savia, G., Tagliaferri, M., Lucantoni, R., Berselli, M.E., Petroni, M.L. (1999). Serum leptin concentration in moderate and severe obesity: Relationship with clinical, anthropometric and metabolic factors. International Journal of Obesity, 23 (10), 1066-1073.

11. Reame, V., Pytlowanciv, E.Z., Ribeiro, D.L., Pissolato, T.F., Taboga, S.R., \& Góes, R.M. (2014). Obesogenic environment by excess of dietary fats in different phases of development reduces spermatic efficiency of wistar rats at adulthood: correlations with metabolic status. Biology of Reproduction, 91 (6).

12. Fernandez, C.D.B., Bellentani, F.F., Fernandes, G.S.A., Perobelli, J.E., Favareto, A.P.A., \& Nascimento, A.F. Diet-induced obesity in rats leads to a decrease in sperm motility. Reproductive Biology and Endocrinology: RB\&E, 9, 32. 
13. Marques, C., Meireles, M., Norberto, S., Leite, J., Freitas, J., Pestana, D. (2016). High-fat diet-induced obesity Rat model: a comparison between Wistar and Sprague-Dawley Rat. Adipocyte, 5 (1), 11-21.
14. Von Diemen, V., Trindade, E.N., Roberto, M., Trindade M. Experimental model to induce obesity in rats 1 Modelo experimental para induzir obesidade em ratos. Acta Cirúrgica Brasileira, 21 (6), 2006-2425.

\section{FERTILITY INDICATORS AND PLASMA LEPTIN LEVELS IN RATS UNDER THE INFLUENCE OF HIGH-CALORIE DIETS}

\section{Summary}

Introduction. The molecular mechanisms underlying the relationship between obesity to male fertility are being actively studied by the scientific community. Leptin is a peptide hormone that is mainly synthesized in adipose tissue and maintains energy homeostasis. In addition, it is actively involved in the regulation of reproductive function through modulation of the hypothalamic-pituitary-gonadal axis. Probably, leptin can be considered as a biomarker that combines metabolic status with the reproductive system of the body.

The aim of the study - to evaluate the effect of high-calorie diets on male fertility and plasma leptin levels.

Research Methods. The study was performed on 30 white nonlinear male rats weighing 250-300 g, which were divided into three groups, 10 males each: the control group of rats (CG) consumed standard food; animals of the experimental groups received a high-fat diet (HFD) and a high-fat/high-sugar diet (HFHS), respectively. The animals were kept on these diets for seven weeks. After euthanasia, morphometric measurements were performed, Lee index, testicular coefficient and visceral fat coefficient were calculated. Blood for the study was taken from the rat tail vessels in eppendorf with heparin. The material was centrifuged at $800 \mathrm{~g}$ for $5 \mathrm{~min}$, then plasma was collected for further studies. Sperm suspension was prepared from the cauda epididymis. The total number of sperm cells and motility were calculated. Sperm vitality were performed by staining of spermatozoa with propidium iodide, and fluorescence was assessed using an Olympus IX73 microscope. The concentration of leptin in blood plasma was determined by enzyme-linked immunosorbent assay.

Results and Discussion. Keeping rats on HFD and HFHS by 7 weeks did not significantly affect body weight gain. The Lee index did not differ significantly between the study groups $(p=0.59)$. However, the coefficient of visceral fat in the HFHS group was $40 \%$ higher compared to CG $(p=0.04)$. We did not find a significant difference between the experimental groups in terms of sperm count $(p=0.72)$, motility $(p=0.63)$ and viability $(p=0.87)$. A diet with high sugar and fat resulted in a $14 \%$ increase in leptin plasma concentrations in rats versus baseline $(p=0.01)$.

Conclusions. Short-term high-fat/high-sugar diet causes metabolic changes, as evidenced by a significant increase in the proportion of adipose tissue and plasma leptin levels.

KEY WORDS: leptin; obesity; high-calorie diets; fertility.

Адреса для листування: Н. М. Козопас, Львівський національний медичний університет імені Данила Галицького, вул. Пекарська, 69, Львів, 79010, Україна, e-mail: nataliia.kozopas@gmail.com. 